\title{
Synthesis, Characterization and Computational Studies of Two Triazaspiro Tetracycles
}

\author{
Felix Odame $^{1, \star}$ and Eric C. Hosten ${ }^{1}$ \\ ${ }^{1}$ Department of Chemistry, Nelson Mandela Metropolitan University, P.O. Box 77000, Port Elizabeth 6031, South Africa \\ *Corresponding author: E-mail: felixessah15@gmail.com \\ Tel.: +27415042684, Fax: +27415044236.
}

Received: $12-12-2017$

\begin{abstract}
Two new triazaspiro tetracycles have been synthesized, the compounds have been characterized using spectroscopy, microanalysis and single crystal X-ray diffractometry. The single crystal X-ray crystallography of 4-methyl-8I,10I,17I-triazaspiro[cyclohexane-1,9I-teracyclo[8.7.02,7.011,16]heptadecane]-1I(17),2I(7I),3I,5I,11I,13I,15I-heptaene (compound I) has been discussed. The DFT computed bond angles have been obtained for both compounds and contrasted with experimental results for compound I. The atoms that make up the frontier orbitals which contribute to the reactivity of the compounds have been discussed.
\end{abstract}

Keywords: Aminophenylbenzimidazole; Triazaspirotetracyclics; 3-methylcyclohexanone; 4-methylcyclohexanone; Frontier molecular orbitals.

\section{Introduction}

The conversion of 2-(2'-aminophenyl)-1H-benzimidazoles to triazatetracycles provides a backbone on which to construct different tetracyclic compounds that are also biologically active. It is well known that amines undergo condensation reactions with aldehydes and ketones but utilization of this transformation in the formation of cyclic amines often requires a more intricate procedure. Thus, cyclic amines have been accessed via a sequence of deprotection followed by intermolecular reductive amination of Boc-protected amino ketones (Boc is tert-butyloxycarbonyl group) under asymmetric transfer hydrogenation conditions. ${ }^{1}$ Cyclizations of diamines and ketones have also been catalyzed by $\mathrm{HY}$ zeolite at $50{ }^{\circ} \mathrm{C}$ under solvent-free conditions yielding benzodiazepines. ${ }^{2}$ Benzodiazepine formation has also been reported to occur in the absence of a catalyst. ${ }^{3} \mathrm{~A}$ three-component allylation and cyanation reactions utilising a ketone and $N$-methoxyamine have been reported, and the high nucleophilicity of the $\mathrm{N}$-methoxyamine and high electrophilicity of the corresponding iminium ion enable the concise synthesis of $\mathrm{X}$-trisubstituted amines in a single step. ${ }^{4} \mathrm{~A}$ fourth method reported in the literature, the treatment of $\mathrm{N}$-tosylaldimines with acetophenone at room temperature has been reported to give the corresponding $N$-tosyl $\beta$-amino ketones in high yields within 6-9 h. Subsequent reduction and cyclization of the compounds in this case afforded 2,4-disubstituted $\mathrm{N}$-tosylazetidines, comprising a three step high-yielding synthesis from aldimines. ${ }^{5}$

Twelve $\mathrm{N}$-glycosyl amines were synthesized using 4,6-O-benzylidene- $D$-glucopyranose and different substituted aromatic amines, including some diamines that resulted in bis-glycosyl amines. Another set of six $N$-glycosyl amines was synthesized using different hexoses and pentoses with 2-(o-aminophenyl)benzimidazole. In these reactions only the 2 -amino group reacted with the hydroxyl groups of 2-(o-aminophenyl)benzimidazole. ${ }^{6}$ Reactions of substituted aldehydes with 2-(o-aminophenyl)benzimidazole have been reported to yield Schiff's bases. ${ }^{7}$ The syntheses of 2-(2-nitrophenyl)-1-benzoyl-1H-benzimidazole derivatives and their reduction to the corresponding 2-benzimidazoylbenzamides have been reported. The compounds were cleanly and efficiently converted to the corresponding 6-arylbenzimidazo[1,2-c] quinazolines by microwave activation using $\mathrm{SiO}_{2}-\mathrm{MnO}_{2}$ as a solid inorganic support. ${ }^{8}$ In our case the products were accessed via a solvent-free method. Some triazatetracycles have been synthesized heating 2-(2-aminophenyl)benzimidazole and aryl aldehydes under reflux in ethanol for $5 \mathrm{~h} .{ }^{9}$ Also triazatetracyclic compounds with substituents on the aryl ring have been synthesized from aminophenylbenzimidazole and substituted aryl aldehydes at room temperature in mixtures of ethanol and acetic acid. ${ }^{10}$ The synthesis of 
1,3,8-triazaspiro[4.5]decane-2,4-diones (spirohydantoins) as a structural class of pan-inhibitors of the prolyl hydroxylase (PHD) family of enzymes for the treatment of anemia has also been reported. ${ }^{11}$

This work presents the synthesis and characterization of two new triazaspiro tetracycles, their characterization with IR, NMR, GC-MS and microanalysis. The bond angles of compounds I and II computed using the functionals B3LYP, B3PW91 and wB97XD have been compared with experimental bond angles of compounds $\mathbf{1}$.

\section{Experimental}

\section{1. Materials and Instruments}

Analytical grade reagents and solvents for the synthesis, such as 2-(2'-aminophenyl)-1H-benzimidazole were obtained from Sigma Aldrich (USA), whilst 4-methylcyclohexanone, tetrahydrofuran, ethanol and 3-methylcyclohexanone were obtained from Merck Chemicals (SA). The chemicals were used as received (i.e. without further purification). ${ }^{1} \mathrm{H}$ and ${ }^{13} \mathrm{C}$ NMR spectra were recorded on a Bruker Avance AV $400 \mathrm{MHz}$ spectrometer operating at $400 \mathrm{MHz}$ for ${ }^{1} \mathrm{H}$ and $100 \mathrm{MHz}$ for ${ }^{13} \mathrm{C}$ using deuterated dimethyl sulfoxide as the solvent and tetramethylsilane as the internal standard. Chemical shifts are expressed in ppm. FT-IR spectra were recorded on a Bruker Platinum ATR Spectrophotometer Tensor 27. Elemental analyses were performed using a Vario Elementar Microcube ELIII. Melting points were obtained using a Stuart Lasec SMP30 whilst the mass spectra were determined using an Agilent 7890A GC System connected to a 5975C VL-MSC with electron impact as the ionization mode and detection by a triple-axis detector. The GC was fitted with a $30 \mathrm{~m} \times 0.25 \mathrm{~mm} \times 0.25 \mu \mathrm{m}$ DB-5 capillary column. Helium was used as the carrier gas at a flow rate of $1.63 \mathrm{~mL} \cdot \mathrm{min}^{-1}$ with an average velocity of $30.16 \mathrm{~cm} \mathrm{~s}^{-1}$ and a pressure of $63.73 \mathrm{kPa}$.

\section{1. 1. 4-Methyl-8 ${ }^{\mathrm{I}}, 10^{\mathrm{I}}, 17^{\mathrm{I}}$-triazaspiro[cyclo- hexane-1,9I-teracyclo $\left[8.7 .0^{2,7} \cdot 0^{11,16}\right]$ heptadecane]-1 $1^{\mathrm{I}}(17), 2^{\mathrm{I}}\left(7^{\mathrm{I}}\right), 3^{\mathrm{I}}, 5^{\mathrm{I}}, 1^{\mathrm{I}}, 13^{\mathrm{I}}$, 15 $\mathrm{I}$-heptaene (I) \\ 2-(2'-Aminophenyl)-1H-benzimidazole $(3.14 \mathrm{~g}$,} $0.015 \mathrm{~mol}$ ) was heated under reflux with $10 \mathrm{~mL}$ of 4 -methylcyclohexanone for $6 \mathrm{~h}$. The reaction mixture was dissolved in ethanol and allowed to stand overnight. The white solid obtained was recrystallized as a white crystal from ethanol:THF (1:1), yield $72 \%$; mp $192-193{ }^{\circ} \mathrm{C}$. IR $\left(v_{\max }, \mathrm{cm}^{-1}\right): 3300(\mathrm{~N}-\mathrm{H}), 2941(\mathrm{C}-\mathrm{H}), 1615(\mathrm{C}=\mathrm{N}), 1530$ $(\mathrm{C}=\mathrm{C}), 1479(\mathrm{C}-\mathrm{N}),{ }^{1} \mathrm{H}$ NMR $(400 \mathrm{MHz}) \delta(\mathrm{ppm}): 7.91(\mathrm{~d}$, $J=7.6 \mathrm{~Hz}, 1 \mathrm{H}, \mathrm{ArH}), 7.82(\mathrm{~d}, J=7.6 \mathrm{~Hz}, 1 \mathrm{H}, \mathrm{ArH}), 7.64(\mathrm{~d}$, $J=6.8 \mathrm{~Hz}, 1 \mathrm{H}, \mathrm{ArH}), 7.26(\mathrm{t}, J=7.6 \mathrm{~Hz}, 1 \mathrm{H}, \mathrm{ArH}), 7.18(\mathrm{q}$, $J=6.8 \mathrm{~Hz}, 2 \mathrm{H}, \mathrm{ArH}), 7.12(\mathrm{t}, J=8.0 \mathrm{~Hz}, 1 \mathrm{H}, \mathrm{ArH}), 6.80(\mathrm{t}$, $J=7.6 \mathrm{~Hz}, 1 \mathrm{H}, \mathrm{ArH}), 6.74(\mathrm{~s}, 1 \mathrm{H}, \mathrm{ArH}), 2.50$ (s, 3H), 2.09 $\left(\mathrm{d}, J=12.8 \mathrm{~Hz}, 2 \mathrm{H}, \mathrm{CH}_{2}\right), 1.59\left(\mathrm{dd}, J_{1}=12.8 \mathrm{~Hz}, J_{2}=12.0\right.$ $\left.\mathrm{Hz}, 2 \mathrm{H}, \mathrm{CH}_{2}\right), 1.00\left(\mathrm{~m}, 2 \mathrm{H}, \mathrm{CH}_{2}\right) .{ }^{13} \mathrm{C}$ NMR $(100 \mathrm{MHz}) \delta$ (ppm): $148.2(\mathrm{C}), 144.8(\mathrm{C}), 142.7(\mathrm{C}), 132.9(\mathrm{CH}), 132.1$ (C), $125.3(\mathrm{CH}), 122.4(\mathrm{CH}), 122.2(\mathrm{C}), 119.6(\mathrm{CH}), 118.6$ $(\mathrm{CH}), 115.9(\mathrm{CH}), 113.1(\mathrm{CH}), 113.0(\mathrm{C}), 74.4(\mathrm{C}), 34.8$ $(\mathrm{CH}), 31.2\left(\mathrm{CH}_{2}\right), 30.0(\mathrm{CH}), 22.2\left(\mathrm{CH}_{2}\right)$. Anal. calcd. for: $\mathrm{C}_{20} \mathrm{H}_{21} \mathrm{~N}_{3}$ : C, 79.17; H, 6.98; N, 13.85. Found: C, 79.05; H, 6.84; N, 13.78. LRMS $\left(m / z, \mathrm{M}^{+}\right)$: Found for $\mathrm{C}_{17} \mathrm{H}_{17} \mathrm{~N}_{3}$ 303.23, calcd. mass 303.40 .

\section{1. 2. 3-Methyl-8 ${ }^{\mathrm{I}}, 10^{\mathrm{I}}, 17^{\mathrm{I}}$-triazaspiro[cyclo- hexane-1,9'-teracyclo $\left[8.7 .0^{2,7} \cdot 0^{11,16}\right]$ heptadecane $]-1^{\mathrm{I}}(17), 2^{\mathrm{I}}\left(7^{\mathrm{I}}\right), 3^{\mathrm{I}}, 5^{\mathrm{I}}, 11^{\mathrm{I}}, 13^{\mathrm{I}}, 15^{\mathrm{I}}$ - heptaene (II)}

2-(2'-Aminophenyl)-1H-benzimidazole $(3.14 \mathrm{~g}$, $0.015 \mathrm{~mol}$ ) was heated under reflux with $10 \mathrm{~mL}$ of 3-methylcyclohexanone for $6 \mathrm{~h}$. The reaction mixture was dissolved in ethanol:diethyl ether (1:1). A white solid was obtained which was recrystallized as white crystals from ethanol:THF (1:1), yield $84 \%$; mp $164-166{ }^{\circ} \mathrm{C}$. IR ( $v_{\max }$, $\left.\mathrm{cm}^{-1}\right): 3315(\mathrm{~N}-\mathrm{H}), 2948(\mathrm{C}-\mathrm{H}), 2922(\mathrm{C}-\mathrm{H}), 1619$ $(\mathrm{C}=\mathrm{N}), 1534(\mathrm{C}=\mathrm{C}), 1481(\mathrm{C}-\mathrm{N}) .{ }^{1} \mathrm{H}$ NMR $(400 \mathrm{MHz}) \delta$ (ppm): 7.91 (d, $J=7.6 \mathrm{~Hz}, 1 \mathrm{H}, \operatorname{ArH}), 7.82(\mathrm{~d}, J=8.0 \mathrm{~Hz}$, $1 \mathrm{H}, \mathrm{ArH}), 7.64(\mathrm{~d}, J=6.8 \mathrm{~Hz}, 1 \mathrm{H}, \mathrm{ArH}), 7.24\left(\mathrm{dd}, J_{1}=7.6\right.$ $\left.\mathrm{Hz}, J_{2}=8.0 \mathrm{~Hz}, 1 \mathrm{H}, \mathrm{ArH}\right), 7.19(\mathrm{~m}, 1 \mathrm{H}, \mathrm{ArH}), 7.10(\mathrm{~d}, J=$ $8.0 \mathrm{~Hz}, 1 \mathrm{H}, \mathrm{ArH}), 6.80\left(\mathrm{dd}, J_{1}=7.2 \mathrm{~Hz}, J_{2}=7.6 \mathrm{~Hz}, \mathrm{ArH}\right)$, $6.71(\mathrm{~s}, 1 \mathrm{H}, \mathrm{ArH}), 2.34\left(\mathrm{~m}, 1 \mathrm{H} \mathrm{CH}_{2}\right), 2.06\left(\mathrm{~m}, 4 \mathrm{H}, \mathrm{CH}_{2}\right)$, $1.86\left(\mathrm{dt}, J_{1}=13.6 \mathrm{~Hz}, J_{2}=13.2 \mathrm{~Hz}, 1 \mathrm{H}, \mathrm{CH}\right), 1.71(\mathrm{~d}, J=$ $10.8 \mathrm{~Hz}, 2 \mathrm{H}, \mathrm{CH}), 1.12\left(\mathrm{dt}, J_{1}=12 \mathrm{~Hz}, J_{2}=10.8 \mathrm{~Hz}, 1 \mathrm{H}\right.$, $\mathrm{CH}), 0.93\left(\mathrm{q}, J=4.8 \mathrm{~Hz}, 3 \mathrm{H}, \mathrm{CH}_{3}\right) .{ }^{13} \mathrm{C} \mathrm{NMR}(100 \mathrm{MHz}) \delta$ (ppm): 148.3 (C), 144.9 (C), 142.8 (C), 132.8 (C), 131.8 $(\mathrm{CH}), 125.1(\mathrm{CH}), 122.4(\mathrm{CH}), 122.2(\mathrm{C}), 119.5(\mathrm{CH})$, $118.6(\mathrm{CH}), 115.8(\mathrm{CH}), 113.2(\mathrm{CH}), 112.9(\mathrm{C}), 75.1(\mathrm{C})$, 43.6 $\left(\mathrm{CH}_{2}\right)$, , 34.6 $\left(\mathrm{CH}_{2}\right), 33.4\left(\mathrm{CH}_{2}\right), 27.6(\mathrm{CH}), 22.4\left(\mathrm{CH}_{3}\right)$, $21.2\left(\mathrm{CH}_{3}\right)$. Anal. calcd. for: $\mathrm{C}_{20} \mathrm{H}_{21} \mathrm{~N}_{3}: \mathrm{C}, 79.17 ; \mathrm{H}, 6.98$; $\mathrm{N}, 13.85$. Found: C, 79.25; H, 6.89; N, 13.88. LRMS $(\mathrm{m} / \mathrm{z}$, $\mathrm{M}^{+}$): Found for $\mathrm{C}_{17} \mathrm{H}_{17} \mathrm{~N}_{3} 303.18$, calcd. mass 303.40 .

\section{2. X-Ray Crystallography}

$\mathrm{X}$-Ray diffraction analysis of compound I was performed at $200 \mathrm{~K}$ using a Bruker Kappa Apex II diffractometer with monochromated Mo Ka radiation $(\lambda=0.71073$ $\AA$ ). . APEXII ${ }^{13}$ was used for data collection and SAINT, ${ }^{12}$ for cell refinement and data reduction. The structures were solved by direct methods using SHELXS-2013, ${ }^{13}$ and refined by least-squares procedures using SHELXL-2013, ${ }^{14}$ with SHELXLE, ${ }^{14}$ as a graphical interface. All non-hydrogen atoms were refined anisotropically. Carbon-bound $\mathrm{H}$ atoms were placed in calculated positions ( $\mathrm{C}-\mathrm{H} 0.95 \AA$ for aromatic carbon atoms and $\mathrm{C}-\mathrm{H} 0.99 \AA$ for methylene groups) and were included in the refinement in the riding model approximation, with Uiso $(\mathrm{H})$ set to $1.2 \mathrm{Ueq}(\mathrm{C})$. The $\mathrm{H}$ atoms of the methyl groups were allowed to rotate with a fixed angle around the $\mathrm{C}-\mathrm{C}$ bond to best fit the experimen- 
tal electron density (HFIX 137 in the SHELX program suite, ${ }^{13}$ with Uiso $(\mathrm{H})$ set to $1.5 \mathrm{Ueq}(\mathrm{C})$. Nitrogen-bound $\mathrm{H}$ atoms were located on a difference Fourier map and refined freely. Data were corrected for absorption effects using the numerical method implemented in SADABS. ${ }^{13}$

\section{3. Computational Studies}

All calculations were performed using the GAUSSIAN program ${ }^{15}$ (version 03). The crystal structure was used as an initial molecular geometry for compound I but compound II was drawn using GAUSSIAN VIEW 03 software. The output files were visualized via GAUSSIAN VIEW 03 software. ${ }^{16}$ The molecular structures of both compounds in the ground state were optimized using DFT with hybrid functionals B3LYP (Becke's three parameter hybrid functional using the LYP correlation functional), ${ }^{17-18}$ B3PW91 and wB97XD with 6-31G++ (d,p) basis set. None of the predicted vibrational spectra having any imaginary frequency prove that optimized geometry is located at the lowest point on the potential energy surface.

\section{Results and Discussion}

\section{1. General Studies}

Aromatic protons in ${ }^{1} \mathrm{H}$ NMR were observed between 7.91 and $6.74 \mathrm{ppm}$ for compound I, whilst the signals for compound II were observed between 7.91 and $6.71 \mathrm{ppm}$. The ${ }^{1} \mathrm{H}$ NMR spectrum of compound gave sig-

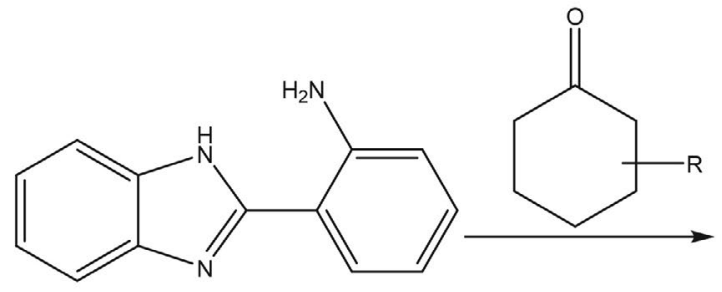

$\mathrm{R}=$ 4-methyl, 3-methyl

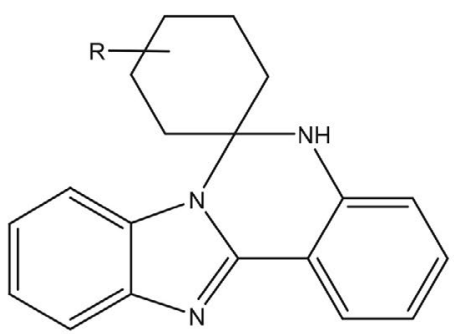

I, II

Scheme 1. Synthesis scheme for the formation of triazaspiro tetracycles I $(\mathrm{R}=4$-methyl) and II (R = 3-methyl).

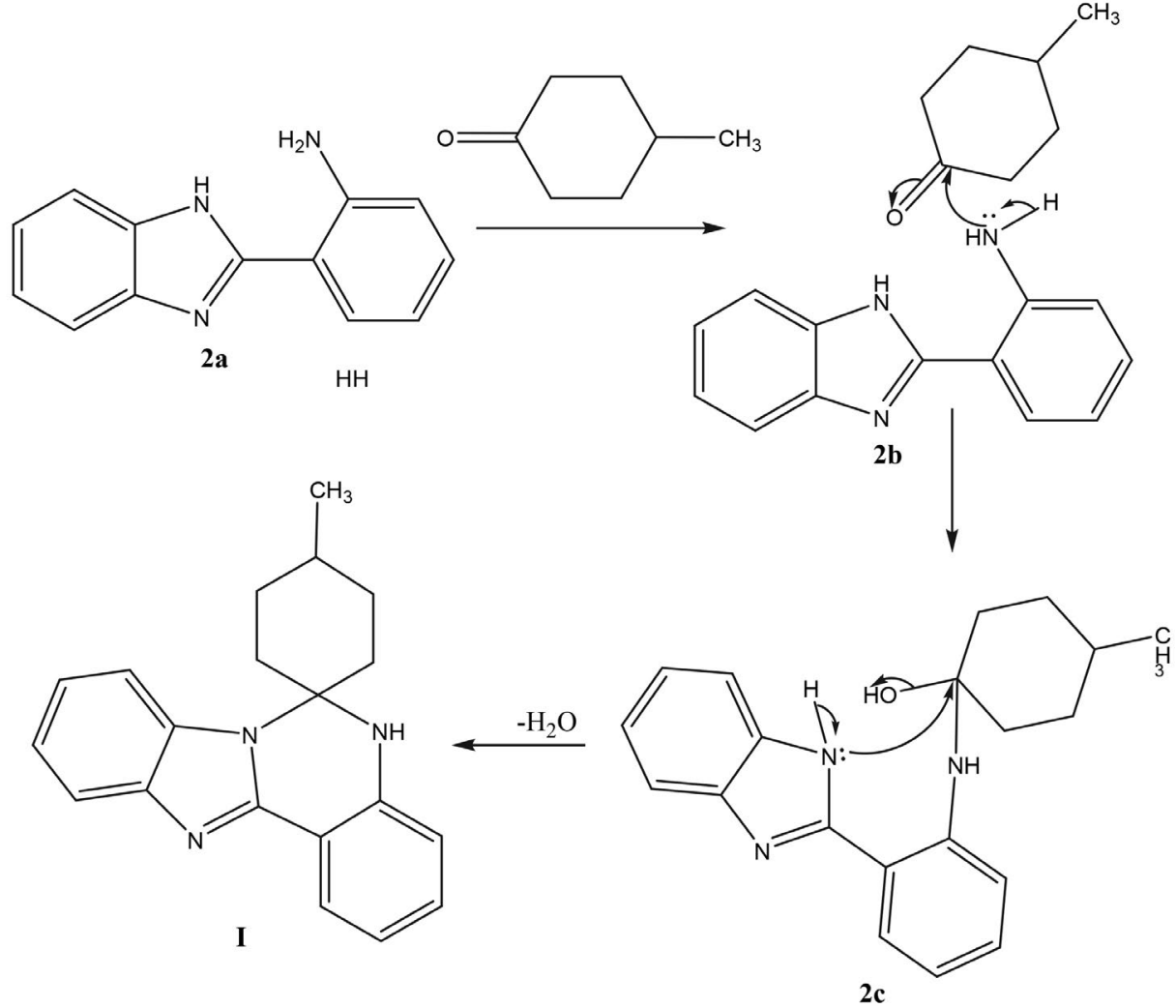

Scheme 2. Proposed mechanism for the formation of compound $\mathbf{I}$. 
nals for aliphatic protons between 2.50 and $1.00 \mathrm{ppm}$ for compound I and 2.34 and $0.93 \mathrm{ppm}$ for compound II. The DEPT spectrum confirmed the presence of four methylene groups in both compounds.

The HMBC spectrum of compound I showed that the signal at $74.4 \mathrm{ppm}$ is within three bonds of the signals at 6.74 an $6.80 \mathrm{ppm}$ confirming the attachment of the carbonyl contributed by 4-methylcyclohexanone to the 2-aminophenyl moiety. In compound II the HMBC spectrum also showed that resonance at $75.1 \mathrm{ppm}$ was with three bonds of the resonances at 115.8 and $113.2 \mathrm{ppm}$ also confirming the attachment of the 3-methylcyclohexanone to the 2 -aminophenyl moiety. Scheme 1 gives the synthesis overview for the formation of two triazaspiro tetracycles.

The proposed mechanism for the formation of triazaspiro tetracyclics is presented in Scheme 2. The reaction is thought to proceed by the attack of the carbonyl carbon of 3-methylcyclohexanone by the lone pair of electrons on the 2-aminophenyl group as shown in $\mathbf{2 b}$. The formation of the hydroxyl group in $2 \mathrm{c}$ allows the lone pair of electrons on the nitrogen to attack the carbon of the hydroxyl group with the loss of water to form $\mathbf{I}$.

\section{2. Reaction Mechanism Monitoring with ${ }^{1} \mathrm{H}$ NMR}

Figure 1 gives the results of the ${ }^{1} \mathrm{H}$ NMR monitoring of the progress of the reaction of 4-methylcyclohexanone with 2-(2'-aminophenyl)-1H-benzimidazole at 20 minutes intervals. Some of the aromatic signals merge into other signals due to the change in their environment after attachment of the ketone and consequently the aromatic ring.

\section{3. Characterization of Crystal Structures}

Compound I was recrystallized as a white solid from ethanol:THF (1:1). The computed and experimental crystallographic data and selected bond angles for compound I are provided in Tables 1 and 2. The ORTEP diagram for compound I at 50\% ellipsoid is presented in Figures 2. Two independent structures were obtained for compound $\mathbf{I}$ and both structures have been computed and discussed. I crystallized in the monoclinic space group P21/n.

The experimentally determined bond angle of N13C121-C126 for compound I was $122.7(1)^{\circ}$ which deviates by between 1.0 to $1.2^{\circ}$ for the computed bond angles of compounds I and II using the B3LYP, B3PW9 and wB97XD functionals at the $6-311+\mathrm{g}(\mathrm{p}, \mathrm{d})$ basis set. The computation of the bond angles of C122-C121-N13 for compounds I and II using the B3LYP, B3PW9 and wB97XD functionals and the $6-311+\mathrm{g}(\mathrm{p}, \mathrm{d})$ basis set gave deviations between 0 and $1.1^{\circ}$ from the experimentally determined bond angle of $118.0(1)^{\circ}$ for compound $\mathbf{I}$. The C122-C11-N11 bond angle for compound I was experimentally determined as $119.5(1)^{\circ}$. The computed bond angles for compounds I and II using the B3LYP, B3PW9 and

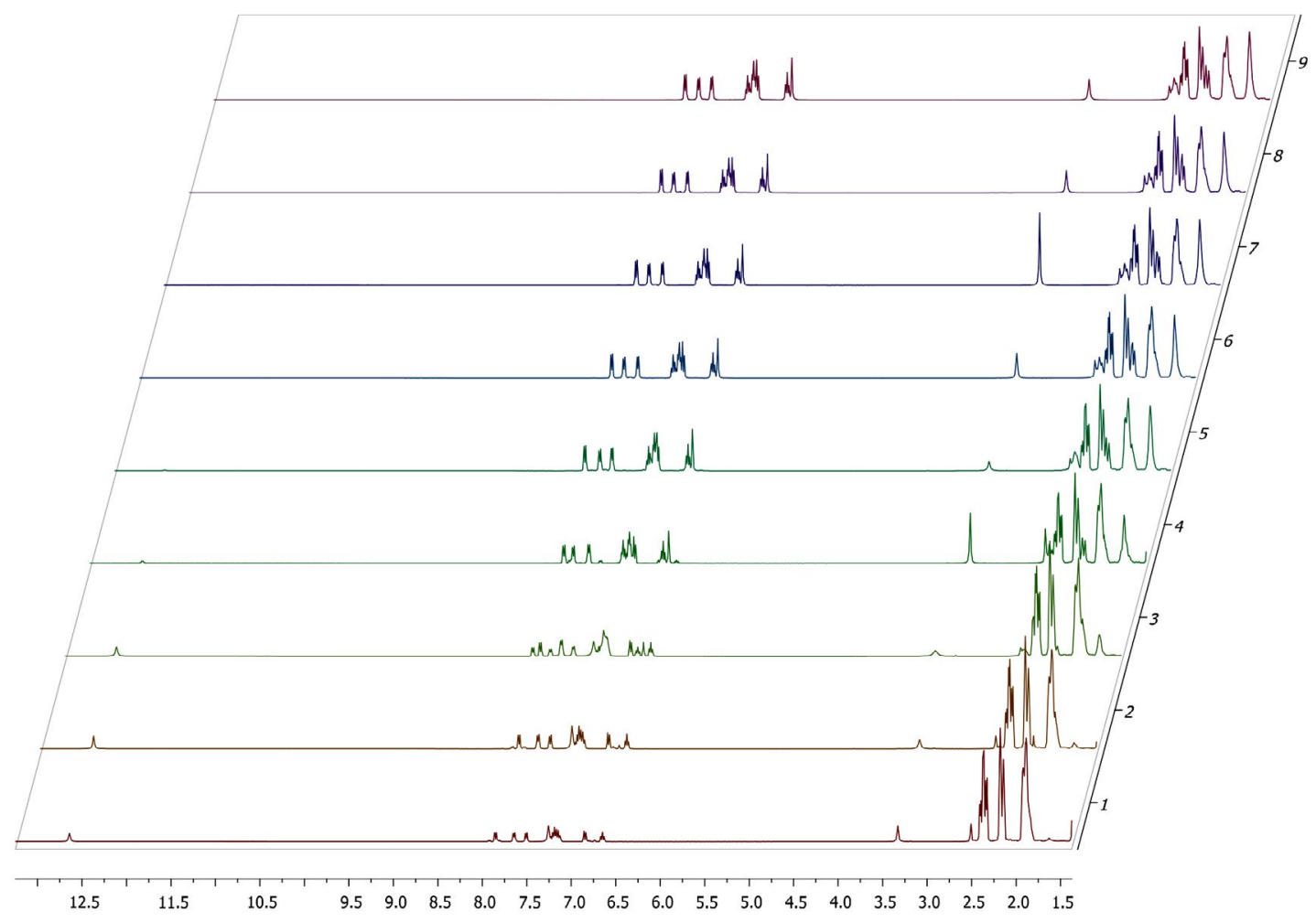

Figure 1. ${ }^{1} \mathrm{H}$ NMR monitoring of the reaction progress of 4-methylcyclohexanone and 2-(2'-aminophenyl)-1H-benzimidazole at 20 minute intervals. 
Table 1. Crystallographic data and structure refinement summary for compound I

\begin{tabular}{|c|c|}
\hline Property & Compound I \\
\hline Formula & $\mathrm{C}_{20} \mathrm{H}_{21} \mathrm{~N}_{3}$ \\
\hline CCDC number & 1550687 \\
\hline Formula Weight & 303.40 \\
\hline Crystal System & Monoclinic \\
\hline Space group & $\mathrm{P} 21 / \mathrm{n}$ \\
\hline$a[\AA ̊ \cap]$ & $12.9495(4)$ \\
\hline$b[\AA]$ & $16.2186(4)$ \\
\hline$c[\AA]$ & $15.6429(3)$ \\
\hline$\alpha\left[^{\circ}\right]$ & 90 \\
\hline$\beta\left[^{\circ}\right]$ & $91.857(1)$ \\
\hline$\gamma\left[^{\circ}\right]$ & 90 \\
\hline$V\left[\AA^{3}\right]$ & $3283.64(14)$ \\
\hline$Z$ & 8 \\
\hline$d\left(\right.$ calc) $\left[\mathrm{g} / \mathrm{cm}^{3}\right]$ & 1.227 \\
\hline $\mathrm{Mu}(\mathrm{MoKa})[/ \mathrm{mm}]$ & 0.074 \\
\hline $\mathrm{F}(000)$ & 1296 \\
\hline Crystal Size $[\mathrm{mm}]$ & $0.19 \times 0.29 \times 0.39$ \\
\hline Temperature (K) & 200 \\
\hline Radiation [Å] & MoKa 0.71073 \\
\hline Theta Min-Max $\left[^{\circ}\right]$ & $2.4,28.3$ \\
\hline Dataset & $-17: 17 ;-21: 21 ;-20: 20$ \\
\hline Tot., Uniq. Data, R(int) & $90703,8160,0.023$ \\
\hline Observed Data $[\mathrm{I}>2.0 \operatorname{sigma}(\mathrm{I})]$ & 6333 \\
\hline Nref, & 8160 \\
\hline Npar & 425 \\
\hline $\mathrm{R}$ & 0.0404 \\
\hline wR2 & 0.1116 \\
\hline$S$ & 1.03 \\
\hline Max. and Av. Shift/Error & $0.00,0.00$ \\
\hline Min. and Max. Resd. Dens. [e/ $\left.\AA^{3}\right]$ & -0.19 \\
\hline Min. and Max. Resd. Dens. [e/ $\left.\AA^{3}\right]$ & 0.25 \\
\hline
\end{tabular}

wB97XD functionals and the $6-311+g(p, d)$ basis set gave deviations of between 1.6 and $2.2^{\circ}$. The computed bond angles of C122-C11-N12 for compounds I and II using the B3LYP, B3PW9 and wB97XD yielded deviations of between 0.3 and $0.7^{\circ}$ from the experimentally determined bond angle of compound I which was $126.7(1)^{\circ}$. The N11C11-N12 bond angle for compound I obtained from experiment was $113.8(1)^{\circ}$. When computed using the B3LYP, B3PW9 and wB97XD functionals at the 6-311+g(p,d) basis set the results gave deviations between 1.1 and $1.8^{\circ}$ from the experimental value. The C11-N11-C111 bond angle for compound I was experimentally determined as 106.2(1) ${ }^{\circ}$. Computation using the B3LYP, B3PW9 and wB97XD functional at the $6-311+g(p, d)$ basis set gave results which deviates from the experimental result by $\pm 0.3^{\circ}$. The experimentally determined C11-N12-C112 bond angle for compound I was $104.3(1)^{\circ}$.

The computed results differed from the experimental values by between 1.1 to $1.4^{\circ}$. The experimentally determined N11-C111-C116 bond angle for compound I was $134.9(1)^{\circ}$. This differs from the computed values by between 0.8 and $1.4^{\circ}$. The N12-C112-C111 bond angle for compound I was experimentally determined as $111.0(1)^{\circ}$, which was approximately the same as the computed values with a difference of $\pm 0.1^{\circ}$. The experimentally determined N12-C112-C113 bond angle for compound I was $128.1(1)^{\circ}$. And this deviated from the computed values by between 0.2 and $0.4^{\circ}$. The experimentally determined bond angles of N11-C111-C112, C121-N13-C131 and N11-C131-N13 were 104.7(1), 118.8(1) and 104.6(1) ${ }^{\circ}$ and differed by $\pm 0.3,3.0$ to 11.1 and 2.8 to $3.1^{\circ}$, respectively. The N11-C131-C136 bond angle for compound I was ex-

Table 2. Summary of theoretical and experimental bond angles of 4-methylcyclohexanone derivative as well as the computed bond angles of 3-methylcyclohexanone

\begin{tabular}{|c|c|c|c|c|c|c|c|}
\hline & & & & ingles $\left({ }^{\circ}\right)$ & & & \\
\hline & & & Compound I & & & Compound II & \\
\hline EXPERIMENTAL & & B3LYP/ & B3PW91/ & wB97XD/ & B3LYP/ & B3PW91/ & wB97XD/ \\
\hline N13-C121-C126 & $122.7(1)$ & 121.6 & 121.6 & 121.8 & 121.6 & 121.6 & 121.7 \\
\hline C122-C121-N13 & $118.0(1)$ & 119.1 & 119.0 & 119.1 & 119.1 & 118.0 & 119.1 \\
\hline C122-C11-N11 & $119.5(1)$ & 121.3 & 121.1 & 121.6 & 121.5 & 121.3 & 121.7 \\
\hline $\mathrm{C} 122-\mathrm{C} 11-\mathrm{N} 12$ & $126.7(1)$ & 126.2 & 126.2 & 126.4 & 126.0 & 126.0 & 126.3 \\
\hline N11-C11-N12 & $113.8(1)$ & 112.5 & 112.7 & 112.0 & 112.5 & 112.7 & 112.0 \\
\hline C11-N11-C111 & $106.2(1)$ & 106.0 & 106.0 & 106.4 & 105.9 & 105.9 & 106.3 \\
\hline C11-N11-C131 & $120.7(1)$ & 125.0 & 125.1 & 124.8 & 125.0 & 125.0 & 128.5 \\
\hline C11-N12-C112 & $104.3(1)$ & 105.7 & 105.4 & 105.4 & 105.6 & 105.4 & 105.4 \\
\hline N11-C111-C112 & $104.7(1)$ & 105.0 & 104.9 & 105.2 & 105.0 & 104.9 & 105.1 \\
\hline N11-C111-C116 & $134.9(1)$ & 133.9 & 133.9 & 133.5 & 134.1 & 134.1 & 133.7 \\
\hline N12-C112-C111 & $111.0(1)$ & 110.9 & 111.0 & 111.1 & 111.0 & 111.0 & 111.1 \\
\hline N12-C112-C113 & $128.1(1)$ & 128.4 & 128.3 & 128.5 & 128.2 & 128.2 & 128.4 \\
\hline C121-N13-C131 & $118.8(1)$ & 121.8 & 113.6 & 129.5 & 129.9 & 129.9 & 129.7 \\
\hline N11-C131-N13 & $104.6(1)$ & 107.4 & 107.7 & 107.2 & 107.4 & 107.7 & 107.3 \\
\hline N11-C131-C136 & 109.3(1) & 111.6 & 110.4 & 109.7 & 107.6 & 110.6 & 119.9 \\
\hline N11-C131-C132 & $111.8(1)$ & 110.3 & 111.7 & 111.5 & 110.8 & 110.8 & 110.8 \\
\hline N13-C131-C132 & $108.9(1)$ & 107.6 & 108.5 & 108.6 & 108.1 & 110.8 & 108.1 \\
\hline
\end{tabular}




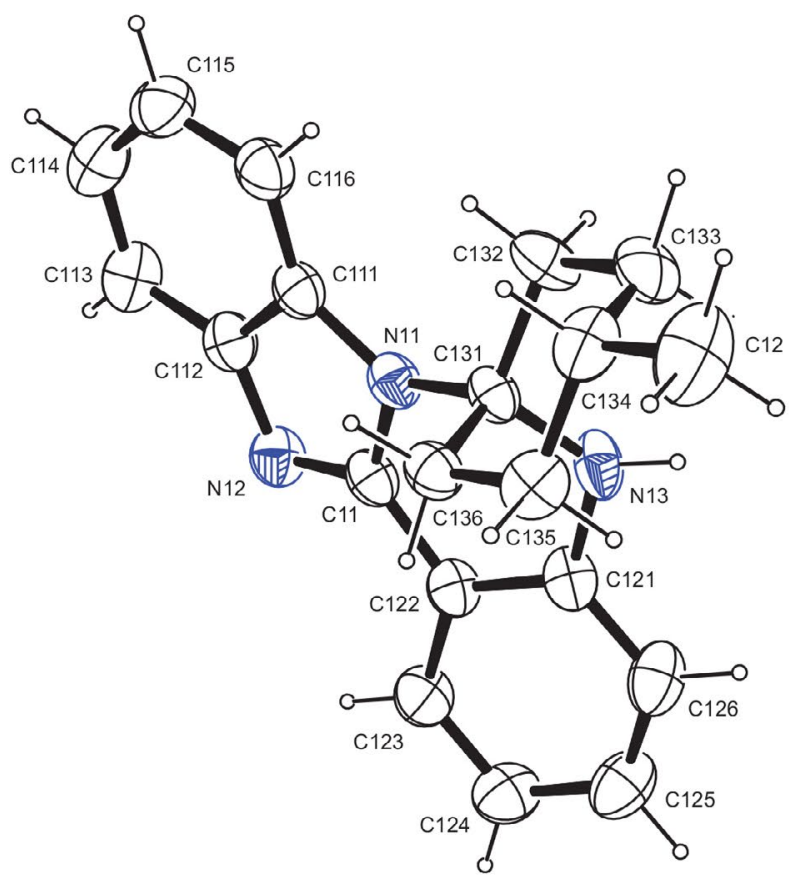

Figure 2. An ORTEP diagram of compound I at 50\% ellipsoid

perimentally determined as $109.3(1)^{\circ}$. The computed values differed by between 0.4 and $10.6^{\circ}$. The experimentally determined bond angle of N11-C131-C132 for compound I was $111.8(1)^{\circ}$. It deviated from the computed values by between 0.1 and $1.5^{\circ}$. The N13-C131-C132 bond angle for compound I was experimentally determined as $108.9(1)^{\circ}$ this deviates by between 0.8 and $1.9^{\circ}$ from the computed values.

\section{4. HOMO-LUMO Analysis}

The HOMO and LUMO are the main orbitals that determine chemical stability of any species. ${ }^{19}$ The HOMO

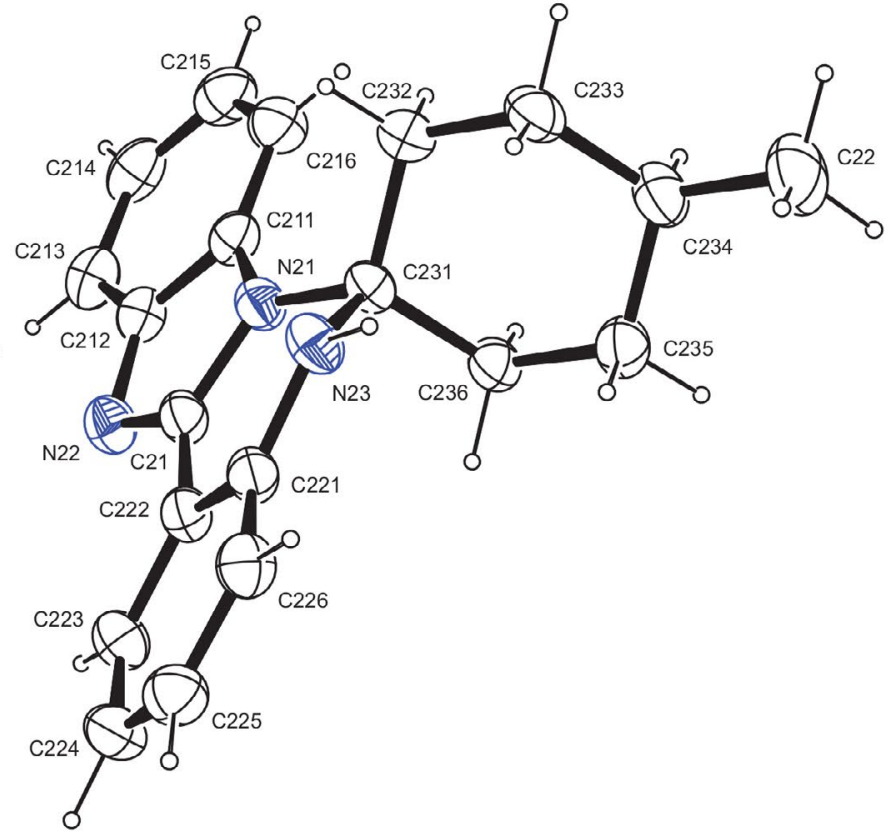

represents the ability to donate an electron whilst the LUMO represents the ability to accept an electron. The energy of the HOMO is directly related to the ionization potential whilst the energy of the LUMO is related to the electron affinity. The energy difference between HOMO and LUMO orbitals, known as the energy gap, determines the stability or reactivity of molecules. ${ }^{20}$ The energy gap is a critical parameter in determining molecular electrical transport properties because it is a measure of electron conductivity. ${ }^{21}$ The hardness of a molecule also corresponds to the gap between the HOMO and LUMO orbitals. ${ }^{22}$

For the different functional and basis sets the HOMO and LUMO are mostly delocalized over the 2 -aminophe-

Table 3. HOMO-LUMO orbitals of compounds I and II

\begin{tabular}{|c|c|c|c|c|c|c|}
\hline & $\begin{array}{c}\text { B3LYP/ } \\
6-31++G \\
(d, p)\end{array}$ & $\begin{array}{c}\text { B3PW91/ } \\
6-31++G \\
(d, p)\end{array}$ & $\begin{array}{c}\text { wB97XD/ } \\
6-31++G \\
(d, p)\end{array}$ & $\begin{array}{c}\text { B3LYP/ } \\
6-31++G \\
(d, p)\end{array}$ & $\begin{array}{c}\text { B3PW91/ } \\
6-31++G \\
(d, p)\end{array}$ & $\begin{array}{c}\text { wB97XD/ } \\
6-31++G \\
(d, p)\end{array}$ \\
\hline & \multicolumn{3}{|c|}{ Compound I (eV) } & \multicolumn{3}{|c|}{ Compound II (eV) } \\
\hline LUMO+4 & -0.26632 & -0.26676 & -0.19315 & -0.26627 & -0.26677 & -0.19278 \\
\hline LUMO+3 & -0.26993 & -0.27042 & -0.19731 & -0.26995 & -0.27050 & -0.19726 \\
\hline LUMO+2 & -0.28531 & -0.28641 & -0.20932 & -0.28549 & -0.28662 & -0.20952 \\
\hline LUMO+1 & -0.34017 & -0.34125 & -0.27447 & -0.34046 & -0.34161 & -0.27468 \\
\hline LUMO & -0.44433 & -0.44683 & -0.38954 & -0.44436 & -0.44691 & -0.38944 \\
\hline HOMO & -0.50413 & -0.50646 & -0.57157 & -0.50423 & -0.50665 & -0.57163 \\
\hline HOMO-1 & -0.51472 & -0.51723 & -0.58780 & -0.51501 & -0.51760 & -0.58781 \\
\hline HOMO-2 & -0.53963 & -0.54062 & -0.61707 & -0.54304 & -0.54398 & -0.62078 \\
\hline HOMO-3 & -0.54610 & -0.54062 & -0.62392 & -0.54862 & -0.54964 & -0.62663 \\
\hline HOMO-4 & -0.55032 & -0.54779 & -0.62811 & -0.55609 & -0.55762 & -0.63309 \\
\hline HOMO-LUMO GAP (eV) & 0.0598 & 0.05963 & 0.18203 & 0.05987 & 0.05974 & 0.18219 \\
\hline
\end{tabular}



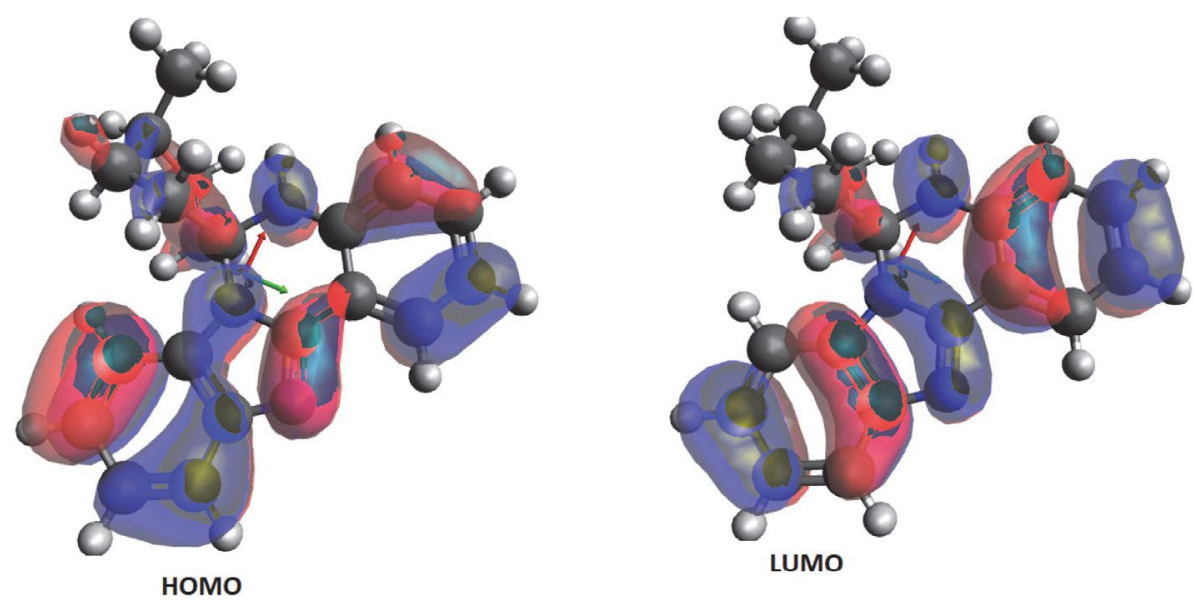

Figure 3. HOMO-LUMO of compound I computed using B3LYP/6-311++g(pd)

nyl- $1 H$-benzimidazole delocalized indicating that during charge transfer in a reaction the molecule is stabilized by delocalization of electrons over the 2-aminophenylbenzimidazole, regardless of the level of theory and the basis set used. Table 3 gives the frontier orbitals for compounds I and II using the B3PLYP, B3PW91 and wB97XD functional at the $6-31++\mathrm{g}(\mathrm{d}, \mathrm{p})$ basis set.

\section{Conclusion}

In conclusion, 4-methyl- $8^{\mathrm{I}}, 10^{\mathrm{I}}, 17^{\mathrm{I}}$-triazaspiro[cyclohexane-1, $9^{\mathrm{I}}$-teracyclo $\left[8 \cdot 7 \cdot 0^{2,7} \cdot 0^{11,16}\right]$ heptadecane $]-1^{\mathrm{I}}(17), 2$ ${ }^{\mathrm{I}}\left(7^{\mathrm{I}}\right), 3^{\mathrm{I}}, 5^{\mathrm{I}}, 11^{\mathrm{I}}, 13^{\mathrm{I}}, 15^{\mathrm{I}}$-heptaene and 3-methyl- $8^{\mathrm{I}}, 10^{\mathrm{I}}, 17^{\mathrm{I}}$-triazaspiro[cyclohexane-1,9 ${ }^{\mathrm{I}}$-teracyclo $\left[8.7 .0^{2,7} \cdot 0^{11,16}\right]$ heptadecane]-1 $1^{\mathrm{I}}(17), 2^{\mathrm{I}}\left(7^{\mathrm{I}}\right), 3^{\mathrm{I}}, 5^{\mathrm{I}}, 11^{\mathrm{I}}, 13^{\mathrm{I}}, 15^{\mathrm{I}}$-heptaene have been synthesized by a solvent-free method and characterized by IR, NMR, elemental analysis and GC-MS. The single crystal X-ray diffraction of compound I has been carried out and the results obtained were discussed. The bond lengths and bond angles of compound $I$ have been compared with the computed bond lengths and bond angles. Whilst the bond lengths are mostly not in agreement with the computed results, the bond angles are very much in agreement with the computed results.

\section{Acknowledgments}

We thank MRC for the research funding (MRCSIR). F. Odame thanks the National Research Foundation for awarding him a postdoctoral Fellowship.

\section{Supplementary Material}

Supplementary data associated with this article can be found, in the online version. CCDC number 1550687 contains the crystal structure associated with this article.

\section{References}

1. G. D. Williams, R. A. Pike, C. E. Wade, M. Wills, Org. Lett. 2003, 22, 4227-4230. DOI:10.1021/ol035746r

2. M. K. Jeganath, K. Pitchumani, ACS Sustainable Chem. Eng. 2014, 2, 1169-1176. DOI:10.1021/sc400560v

3. F. Odame, P. Kleyi, E. Hosten, R. Betz, K. Lobb, Z. Tshentu, Molecules 2013, 18, 14293-14305.

DOI:10.3390/molecules181114293

4. Y. Kurosaki, K. Shirokane, T. Toishi, T. Sato, N. Chida, Org. Lett. 2012, 14, 2098-2101. DOI:10.1021/ol300622r

5. B. K Goering. Ph.D. Thesis, Cornell University, 1995.

6. T. M. Das, C. P. Rao, E. Kolehmainen, Carbohydr. Res. 2001, 334, 261-269. DOI:10.1021/ol300622r

7. Y. S. Chhonker, B. Veenu, S. R. Hasim, N. Kaushik, D. Kumar, P. Kumar, Eur. J. Chem. 2009, 6(S1), S342-S346

8. H. Pessoa-Mahana, C. D. Pessoa-Mahana, R. Salazar, J. A. Valderrama, E. Saez, R. Araya-Maturana, Synthesis 2004, 3, 436-440. DOI:10.1055/s-2004-815924

9. P. P. Joshi, S. G. Shirodkar, World J. Pharm. Pharm. Sci. 2014, 3(9), 950-958.

10. B. A. Insuasty, H. Torres, J. Quiroga, R. Abonia, R. Rodriguez, M. Nogeras, A. Sanchez, C. Saitz, S. L. Avarez, S. A. Zacchino, J. Chil. Chem. Soc. 2006, 51(2), 927-932.

DOI:10.4067/S0717-97072006000200018

11. P. Vachal, S. Miao, J. M. Pierce, D. Guiadeen, V. J. Colandrea, M. J. Wyvratt, S. P. Salowe, L. M. Sonatore, J. A. Milligan, R Hajdu, A. Gollapudi, C. A. Keohane, R. B. Lingham, S. M. Mandala, J. A. DeMartino, X. Tong, M. Wolff, D. Steinhuebel, G. R. Kieczykowski, F. J. Fleitz, K. Chapman, J. Athanasopoulos, G. Adam, C. D. Akyuz, D. K. Jena, J. W. Lusen, J. Meng, B. D. Stein, L. Xia, E. C. Sherer, J. J. Hale, J. Med. Chem. 2012, 55, 2945-295. DOI:10.1021/jm201542d

12. APEX2, SADABS and SAINT. Bruker AXS Inc: Madison, WI, USA, 2010.

13. G. M. Sheldrick, Acta. Cryst. A 2008, 64, 112-122. DOI:10.1107/S0108767307043930

14. C. B. Hübschle, G.M. Sheldrick, B. Dittrich, J. Appl. Cryst. 2011, 44, 1281-1284. DOI:10.1107/S0021889811043202 
15. M. J. Frisch, G. W. Trucks, H. B. Schlegel, G. E. Scuseria, M. A. Robb, J. R. Cheeseman, J. A. Montgomery Jr., T. Vreven, K. N. Kudin, J.C. Burant, J. M. Millam, S. S. Iyengar, J. Tomasi, V. Barone, B. Mennucci, M. Cossi, G. Scalmani, N. Rega, G.A. Petersson, H. Nakatsuji, M. Hada, M. Ehara, K. Toyota, R. Fukuda, J. Hasegawa, M. Ishida, T. Nakajima, Y. Honda, O. Kitao, H. Nakai, M. Klene, X. Li, J. E. Knox, H. P. Hratchian, J. B. Cross, V. Bakken, C. Adamo, J. Jaramillo, R. Gomperts, R. E. Stratmann, O. Yazyev, A. J. Austin, R. Cammi, C. Pomelli, J. W. Ochterski, P. Y. Ayala, K. Morokuma, G. A. Voth, P. Salvador, J. J. Dannenberg, V. G. Zakrzewski, S. Dapprich, A. D. Daniels, M. C. Strain, O. Farkas, D. K. Malick, A. D. Rabuck, K. Raghavachari, J. B. Foresman, J. V. Ortiz, Q. Cui, A. G. Baboul, S. Clifford, J. Ioslowski, B. B. Stefanov, G. Liu, A. Liashenko, P. Piskorz, I. Komaromi, R. L. Martin, D. J. Fox, T. Keith, M. A. AlLaham, C. Y. Peng, A. Nanayakkara, M. Challacombe, P. M. W. Gill, B. Johnson, W. Chen, M.W. Wong, C. Gonzalez, J.A. Pople, Gaussian 03, Revision E.01, Gaussian Inc, Wallingford, CT, 2004.
16. R. Dennington II., T. Keith, J. Millam, GaussView, Version 4.1.2, Semichem Inc, Shawnee Mission, KS, 2007.

17. A. D. Becke, J. Chem. Phys. 1993, 98, 5648-5652. DOI:10.1063/1.464913

18. C. Lee, W. Yang, R. G. Parr, Phys. Rev. B, 1988, 37, 785-789. DOI:10.1103/PhysRevB.37.785

19. D. F. V. Lewis, C. D. V. Ioannides, Xenobiotica, 1994, 24, 401408. DOI:10.3109/00498259409043243

20. L. Padmaja, R. C. Kunar, D. Sajan, I. H. Joe, V. S. Jayakunmar, G. R. Pettit, O. F. Nielsen, J. Raman Spectrosc. 2009, 40, 419-428. DOI:10.1002/jrs.2145

21. A. Poiyamozhi, N. Sundaraganesan, M. Karabacak, O. Tanriverdi, M. Kurt, J. Mol. Struc. 2012, 1024, 1-12.

DOI:10.1016/j.molstruc.2012.05.008

22. P. Udhayakala, A. Jayanthi, T. V. Rajendiran, S. Gunasekaran, Arch. Appl. Sci. Res. 2011, 3(4), 424-439.

DOI:10.1002/jrs.2145

\section{Povzetek}

Sintetizirali smo dva nova triazaspiro tetraciklična sistema, obe spojini karakterizirali s pomočjo spektroskopskih metod in elementne mikroanalize, $\mathrm{v}$ enem primeru pa izvedli tudi rentgensko difrakcijo na monokristalu. Rentgenska kristalna analiza spojine 4-metil- $8^{\mathrm{I}}, 10^{\mathrm{I}}, 17^{\mathrm{I}}$-triazaspiro[cikloheksan-1,9的-teraciklo[8.7.0 $0^{2,7} \cdot 0^{11,16}$ ] heptadekan]-1 $1^{\mathrm{I}}(17), 2^{\mathrm{I}}\left(7^{\mathrm{I}}\right), 3^{\mathrm{I}}, 5^{\mathrm{I}}, 11^{\mathrm{I}}$, $13^{\mathrm{I}}, 15^{\mathrm{I}}$-heptaen (I) je služila za primerjavo eksperimentalnih veznih kotov z računskimi DFT rezultati, pridobljenimi za obe spojini. Ker so energije mejnih molekulskih orbital ključnega pomena za reaktivnost molekul, smo izračunali tudi njihove energije in jih primerjali med seboj. 